\title{
Thin Political Markets: The Soft Underbelly of Capitalism
}

\section{Citation}

Ramanna, Karthik. "Thin Political Markets: The Soft Underbelly of Capitalism." California Management Review 57, no. 2 (Winter 2015): 5-19.

\section{Published Version}

http://www.jstor.org/stable/10.1525/cmr.2015.57.2.5

\section{Permanent link}

http://nrs.harvard.edu/urn-3:HUL.InstRepos:16244995

\section{Terms of Use}

This article was downloaded from Harvard University's DASH repository, and is made available under the terms and conditions applicable to Open Access Policy Articles, as set forth at http:// nrs.harvard.edu/urn-3:HUL.InstRepos:dash.current.terms-of-use\#OAP

\section{Share Your Story}

The Harvard community has made this article openly available.

Please share how this access benefits you. Submit a story.

\section{Accessibility}




\title{
Thin Political Markets: \\ The Soft Underbelly of Capitalism
}

- Karthik Ramanna

\begin{abstract}
“Thin political markets” are the processes through which some of the most complex and critical institutions of our capitalist system are determined - e.g., our accounting-standards infrastructure. In thin political markets, corporate managers are largely unopposed - because of their own expertise and the general public's low awareness of the issues. This enables managers to structure the "rules of the game" in self-serving ways. The result is a structural flaw in the determination of critical institutions of our capitalist system, which, if ignored, can undermine the legitimacy of the system. I provide some ideas on how to fix the problem.
\end{abstract}

This article is based on my book Political Standards, The University of Chicago Press, 2015. I am grateful to the many individuals whose feedback improved the book. For suggestions on this article, I thank Joe Badaracco, Jon Cell, Bob Kaplan, Mal Salter, Bob Simons, Jake Soll, Eugene Soltes, Rahula Strohl, and Lou Wells.

Forthcoming in the California Management Review. 
Imagine you are Shaquille O’Neal at the height of his dominance. Given your eminence and expertise, you have been asked by the commissioner of the National Basketball Association (NBA) for input on how to improve the game. As O'Neal, you know you are a poor free-throw shooter but a dominant inside player. So you decide this is your shot at improving your ability to score. You propose that all dunks should be worth four points instead of two. You also propose that players should get four free throws if they are fouled on a dunk instead of two. The NBA, deferring to your wisdom and experience, institutes these proposals. Now you, as O’Neal, already commanding the scene, have total control.

Sound like a good idea? Yes, perhaps, if you are O’Neal. But absolutely not, if you are any other player - or a fan. In fact, if something like this were really to happen in the world of basketball, there would probably be a public revolt. And rightly so. But strangely, situations such as this are routinely occurring in the world of business rulemaking. And, because few from the public are actively keeping tabs, the Shaqs of finance and industry are getting away with it.

For instance, look at our system of accounting rules - known as Generally Accepted Accounting Principles or GAAP. This system is at the heart of the modern market economy. Good accounting rules are to capitalism what good plumbing is to your home. You don't think about the intricacies and structure of your home's plumbing, but if it doesn't work, your home would scarcely be habitable. The same is true of accounting rules. Although out of the day-to-day eye of even most businesspersons, accounting rules are essential to defining and measuring fundamental notions such as "profits" and "assets." The efficient allocation of capital and the effective evaluation of investments in a market economy depend in part on the nature of accounting rules.

For all of its importance to our economy, there has been very little public light shed on the nature of accounting rules in the United States and beyond. Accounting rules are a social construction. Contrary to widespread perception, there are no "natural laws" when it comes to accounting rules - there are no absolute rights and wrongs. GAAP in the United States and elsewhere is determined through a political process dominated by experts immersed in the various complex specialty-functions that underlie modern business. Like for other rules governing business, the political process underlying accounting rules can be led astray and can become "captured" by the specialists running the show. So it is imperative that from time-to-time we engage in a systematic evaluation of the political process.

For the last ten years, I have been engaged in such an evaluation for our system of accounting rules. I have studied numerous specific accounting issues largely outside the public's attention, such as accounting related to mergers and acquisitions, related-party transactions, and foreign currency translations. I have also studied the rule-making process in various jurisdictions - the United States, China, India, and the European Union. Across the span of my work, three basic findings have emerged. The findings can 
be useful in understanding how rules are set for many other business issues, including the governance of our banks, the auditing of our listed companies, and the standards by which our insurance industry operates.

First, on any given specific accounting issue, there are a usually just a handful of individuals - somewhere between five and 50 people in the world - that are truly experts on the subject (the Shaqs). These individuals - these subject-matter experts - are also usually the people with the strongest concentrated commercial interest in the outcome. So, importantly, there is a co-location of expertise and interest.

Second, and perhaps not surprisingly given the first finding, the "rules of the game" that emerge from the political process are subtly but in significant ways tailored to favor these experienced few that really understand the issue.

And third, there is no unequivocal villain in this story. There is no one person or group or organization that one can point to and say, "There's the problem; that's the institution 'capturing' the system.” Because nobody is really an expert on and deeply interested in everything. The outcome of the political process looks like it was produced by a quilt of special interests. Experts show up when they really understand the issue at hand. And when they show up, there is often nobody sitting across the table from them supporting an alternative. So, not surprisingly, they get their way - the rules subtly favor their interests.

These three findings provide an insight into the nature of the accounting system underlying our modern market economy - an insight into the nature of capitalism's plumbing. And it appears that accounting rule-making is a patchwork of various informed interests seeking their own ends. But there is another, more important conclusion from this investigation - the problem in accounting foreshadows a broader problem with how some of the most critical institutions of capitalism are determined. I call this the problem of "thin political markets."

Let me illustrate with an example.

\section{A thin political market in operation}

The date is May 31, 2000, and the location is an obscure office building in Norwalk, Connecticut, that houses the offices of the Financial Accounting Standards Board or FASB. The FASB is a private, not-for-profit organization that has an implicit charter from the Securities \& Exchange Commission (SEC) and from Congress to determine accounting rules for U.S. non-governmental entities. One reason why Congress and the SEC have created this private organization to oversee accounting rule-making is because the government recognizes that it does not have the know-how to do this directly.

On this date in May 2000, in their offices in Norwalk, the FASB was discussing accounting rules for mergers and acquisitions (M\&A). M\&A between and across 
companies are a critical institution of our modern market-capitalist economy. In ideal cases, they allow companies to fold into each other to unleash synergies that can sustain and grow the economy. Further, they constitute a core element of the "market for corporate control" - the process through which floundering companies and their managements are held to account by the rigors of the marketplace, embodying the creative destruction at the heart of capitalism.

It turns out that the members of the FASB were not the only ones at their board meeting to discuss accounting for M\&A in May, 2000. There were representatives from the accounting firms Arthur Anderson, Deloitte, and PriceWaterhouse Coopers and from the investment banks Goldman Sachs and Morgan Stanley also attending the meeting. ${ }^{1}$

It is noteworthy that the two biggest investment banks of the day were attending a private meeting of the accounting regulator as accounting rules for mergers and acquisitions were being decided. But, on some level, this makes perfect sense, because who understands M\&A better than the investment banks? After all, facilitating M\&A is what investment banks do.

Mergers and acquisitions are a big deal in any market economy. In the last 30 years, the size of M\&A deals in the U.S. has approximated $\$ 44$ trillion. $^{2}$ And these deals have made the investment banks and investment bankers very rich. But there has been a lot of academic work in business schools suggesting that, on average, M\&A deals destroy value for shareholders. This evidence comes from looking at changes in the stock prices of acquiring firms on the announcement dates of acquisitions - those changes are, on average, negative. ${ }^{3}$

When confronted with this evidence, managers of acquiring firms often argue that stock markets cannot immediately appreciate the complexities and nuances of valuecreation from an acquisition. To judge an acquisition's performance one requires more long-term metrics, they say. This is where accounting rules for M\&A come in. After all, accounting rules are supposed to provide investors and other stakeholders with long-term accountability metrics of firm and managerial performance.

The key issue in accounting for M\&A is what to do with the purchase premium. The purchase premium is the excess an acquiring firm pays for a target firm over the current value of the target's assets less the target's liabilities. Say I bought your local coffee shop for $\$ 100,000$. The shop has assets of $\$ 75,000$, but debt of $\$ 30,000$. Then, the assets less the debt are valued at $\$ 45,000$, and my purchase price of $\$ 100,000$ reflects a premium of $\$ 55,000$. Accountants refer to this excess or purchase premium as "goodwill." So the key issue in accounting for M\&A is how to account for acquired goodwill.

In theory, acquired goodwill generally represents future profits that an acquiring firm hopes to actualize from a merger with a target firm. These future profits might be realized by synergistically combining the two firms - for example, by introducing the target firm's customer base to the acquiring firm's product line. 
If we are going to create sound accounting for M\&A, then as the revenues associated with these hypothesized future profits are recognized in an acquiring firm's income statement, the associated costs must also be recognized. The idea here is pretty basic. For a good measure of profit, one needs to deduct from revenues the costs associated with generating those revenues. In the case of M\&A, these costs include the cost of acquiring goodwill - since without acquiring such goodwill, the revenues and profits wouldn't have been realized.

In practice, it is difficult to know precisely which revenues in the future are directly related to an acquisition. So, to create an approximate matching of revenues to costs, acquiring firms were required to spread the cost of acquired goodwill over the period they estimated the revenues from an acquisition to accrue. For instance, if the cost of goodwill from an acquisition was $\$ 100$ million and the revenues from that acquisition were expected to be generated over 10 years, the acquiring firm would recognize \$10 million of goodwill as an expense in its income statement each year.

The investment banks present at the FASB meeting to discuss accounting for M\&A in May, 2000, did not like this approach. The \$10 million expense each year created a "drag” on acquiring firms' income statements. This made the acquirers look less profitable, which, in turn, was bad for business for the investment banks. So, on that day in May, 2000, the investment banks suggested another approach.

Instead of expensing a portion of goodwill every year, they suggested, why not ask the managers of the acquiring firms to tell us, on a time-to-time basis, whether the goodwill was still worth its face value. The manager can be asked to generate a periodic "fair value" estimate of goodwill, they said. If that fair-value estimate is above the goodwill's face value, no expense is required. If it is below the face value, the acquiring firm will take a loss to the extent of the difference.

There are two problems with this approach. The first problem is that even as revenues associated with an acquisition are being recognized in a firm's income statement, its costs - particularly the costs of goodwill - are not. This violates a basic premise of good accounting and accountability - that profit equals revenues minus costs.

The second problem is as follows. If you ask a manager what is the current fair value of the future profits he expects to generate from an acquisition, you are unlikely to receive a number that is objectively verifiable. The manager's estimate is as good as his incentives to skew his own performance. If the manager wants to look good, he can generate a high fair-value estimate for the goodwill and thus avoid taking an expense to the firm's income statement.

Thus, there are serious concerns with the proposal the investment banks were advancing at the May 2000 meeting with the FASB. But the investment banks had allies. The audit firms also at that meeting endorsed the investment banks' position. And, at another private FASB board meeting on the subject, this one in September 2000, the board heard from other experts on M\&A. Cisco Systems, at the time one of the world's 
most valuable companies and a serial acquirer, the Technology Network, an industry association representing M\&A-hungry Silicon Valley firms, and Merrill Lynch, the other big investment bank, were all represented at the September meeting. These groups lobbied for accounting rules for M\&A that were substantially similar to those advanced by the guests at the May meeting. ${ }^{4}$

By February of 2001, the FASB issued new accounting rules that were largely in line with the position advocated by the investment banks and their allies. Goodwill was no longer to be regularly expensed on the income statement. It was only to be expensed when managers of acquiring firms determined via fair-value estimates that it had lost value. ${ }^{5}$ Thus, a multi-trillion dollar industry where long-term performance measurement is key to ensuring that value is not destroyed ends up with accounting rules that seem inconsistent with even basic tenets of what constitutes a profit.

Of course, it is reasonable to ask how these new rules are actually being implemented. After all, it is possible that managers are not abusing their discretion to determine the fair value of goodwill. In a coauthored study, I investigated how often managers appropriately own up to botched-up acquisitions by recognizing a timely goodwill loss on their firms' income statements. In cases where a goodwill loss was very likely due, the study found that only $31 \%$ of firms faithfully recognized the loss. The remaining $69 \%$ of firms were driven by a number of self-serving motives to avoid such a loss. One such motive is the managers' own bonuses - if a goodwill loss is likely to affect the acquiring-firm CEO's bonus, he is less likely to recognize the loss. ${ }^{6}$

The case of Cisco Systems, one firm that lobbied for the highly discretionary M\&A accounting rules we have today, illustrates this point. Among market experts, Cisco is known for its aggressive use of M\&A. As of the fiscal year ended July 2013, the company had a goodwill balance of nearly $\$ 22$ billion on its books, against total assets of about $\$ 101$ billion. $^{7}$ And, despite a nearly 70\% decline in its market value from 2000 through 2001 (about \$350 billion), a decline that has largely persisted through 2013, the company has not recorded any substantial goodwill-related loss in its financial statements over that period. But, over that period, its CEO, John Chambers, has netted over \$200 million in pay. The highly subjective goodwill rules the company helped put in place have facilitated in part this accounting feat.

And so, in the process to determine accounting for M\&A, informed specialinterest groups such as investment banks and frequent corporate acquirers, facing little opposition to their agenda from the general public and its intermediaries, were able to secure rules that favored their own interests. With trillions of dollars and the effective allocation of investments in our capital markets at stake, any individual with investments in the stock market or with a broad stake in the U.S. economy should be at least slightly concerned.

If the costs to the rest of us are so real, why, one might ask, were the audit firms on board as this all happened? Why did they not step in and intervene for ordinary investors? After all, auditors have to certify, under threat of liability, the financial 
statements of the firms involved. And, if the fair-value estimates on goodwill are so unverifiable and if managers are gaming those estimates, wouldn't the auditors be exposing themselves to such liability?

The issue here is that the determination of audit rules - like the determination of accounting rules for M\&A - is a process occurring largely outside the public eye. The audit rules are influenced by the audit firms themselves, because they have the most relevant expertise on the matter.

Consider, in particular, the auditing rule that deals with auditors' responsibilities on the kinds of fair-value estimates managers have to make when accounting for goodwill from M\&A. This rule - known to insiders as "SAS 101" - creates broad insulation from liability for the auditors involved, provided they follow a pre-specified protocol of actions. In justifying this rule, the auditing standard-setter implied that fairvalue estimates are inherently so unreliable that it would be unreasonable to hold auditors liable for their abuse. ${ }^{8}$ This observation is especially ironical because audit firms were supporting the use of such fair-value estimates when lobbying on the determination of accounting standards!

For instance, when lobbying on what goodwill accounting rules should look like in early 2001, the audit firm Ernst \& Young did not resist the use of highly subjective fair-value estimates to infer goodwill write-offs. ${ }^{9}$ But when later challenged in a shareholder lawsuit for not appropriately flagging goodwill write-off avoidance in a client's financial reports, the audit firm took another tack. Its lawyers argued in a brief to the court considering the lawsuit that fair-value estimates are "inherently judgmental and predictive,” reflecting “opinions about what may occur in the future.” Moreover, the brief added, Ernst \& Young's own liability was limited because "an auditor does not make predictions about the company's future business prospects.”"10

These clever arguments about the subjectivity of the goodwill rules carried the day in the lawsuit, but Ernst \& Young (or, for that matter, any other large audit firm) has not been called to account for its own inconsistency in supporting the introduction of such accounting rules in the first place.

The preceding narrative on how some of our M\&A accounting rules came to be is not unique. Subtly and seemingly inoffensively, across a number of different issue areas and a number of geographies, special interests with the information edge on a given esoteric issue in accounting standard-setting have been able to shape the rules of the game to benefit themselves. This is what I refer to as the problem of thin political markets.

\section{Understanding thin political markets}

A thin political market, at its essence, has two basic features. The first is that a concentrated commercial interest, also known as a "special-interest group," has deeply relevant expertise on the issue at hand. Put differently, there is a co-location of interest 
and expertise in the political process. This was the case with the investment banks on M\&A accounting described earlier.

The second is that the public interest - also known as the "general interest" - is diffuse. It is diffuse because the specific issue at hand has a small individual impact on each member of the public. It is also diffuse because the issue at hand is not salient in the public's mind. It is not a hot, current-affairs topic like Medicare or Social Security. Instead, it is a "boring” topic like accounting rules - one doesn't often encounter dinner party conversations lamenting the state of accounting rule-making.

At first glance, the features of a thin political market might appear quite similar to the features that define the classic collective-action problem that political scientists have been studying for at least the past fifty years. ${ }^{11}$ The collective-action problem arises in political processes where a few big players dominate many small players because the many small players have little individual incentive to organize themselves. Think a giant mining company trying to loosen environmental standards in a country - the residents of that nation might care, but maybe not enough to resist the concentrated onslaught of the mining company.

Social-science research has made a lot of progress in understanding the collectiveaction problem and managing its key implication - the possibility of regulatory "capture" by the big players in a political process. A vibrant stream of research, including work by the late Nobelist Elinor Ostrom, has explored how communities can address the collective-action problem and thus attenuate the chances of regulatory capture. ${ }^{12}$

Unfortunately, the problem of thin political markets is distinct from the simple collective-action problem. In two powerful ways it is more subtle - and thus potentially more dangerous.

First, in a thin political market the source of big players' expertise - the source of their knowledge advantage - is experience based. This means that the knowledge they bring is tacit or implicit rather than codified or explicit. ${ }^{13}$ For instance, the reason large auditing firms like Ernst \& Young are so influential in the determination of accounting rules (beyond their monetary incentives to shape the rules) is that in their day-to-day business they acquire experience that gives them unique insights into what kind of rules will work and what will not.

In a classic collective-action situation, we've learned to reduce the threat of big players capturing regulations by bringing in outside experts who don't have strong commercial interests in the outcome. In a thin political market, such experts don't exist. For instance, in the case of accounting rules, those who might otherwise serve as the “outside experts" - e.g., accounting professors - cannot really substitute for the knowledge of insiders such as the large audit firms, because they are not in the practice of auditing. The implication here is that in thin political markets it is impossible to separate commercial interest in the outcome from relevant expertise to determine the outcome. 
The second distinction between the problem of thin political markets and classic collective action is that thin political markets occur in areas of low salience with the general public. The capture of regulations by big players (or special-interest groups) is a threat in many areas of public governance, but a relatively higher awareness among the public of this possibility induces intermediaries such as politicians or the media to act as safeguards for the public interest.

For instance, on high-awareness regulatory issues such as healthcare reform, politicians seeking reelection and the media seeking to attract readership are more vigilant. ${ }^{14}$ By contrast, the inconspicuousness of issues being determined in thin political markets - e.g., accounting rules - means there is little monitoring of the special interests by public intermediaries. Politicians don't run election campaigns on the promise to fix accounting rules, and the media can seldom be bothered with such complex issues either.

The problem of thin political markets in the determination of accounting rules has implications for us all. As I noted earlier, accounting is a critical institution in the functioning of modern market capitalism. If accounting rules are opportunistically subverted in ways that benefit an informed few, the rest of us are misled in our investment decisions at potentially great cost.

But thin political markets are not limited to the context of accounting rules. Other esoteric areas of setting the rules of the game for the capitalist system are also likely to be thin political markets. For instance, the determination of rules for auditing of companies, the determination of actuarial rules, and the determination of bank-governance rules can all be described as thin political markets. Each of these areas is critical to the modern capital-market system, each is dominated by relevant industry experts, and each is largely outside the public eye and intermediaries for the public. Even as a business-school professor, I seldom attend cocktail parties where the state of actuarial rule-making is the subject of informed chatter.

The problem of thin political markets does not bode well for the long-term legitimacy of market capitalism. For capitalism to work, for self-interested profit-seeking by competitive firms to deliver aggregate prosperity, we must get certain basic rules of the game right. For instance, markets are not "efficient” in the sense of maximizing aggregate wealth if there is collusion and information asymmetry. But if our market system is operating such that our accounting and auditing rules are being gamed by a few key players, then collusive and manipulative outcomes are likely. Markets under such circumstances, rather than creating total wealth, merely serve to reapportion wealth from uninformed to informed players.

These concerns notwithstanding, there is a curious oddity about thin political markets. The various individuals, firms, and organizations that dominate thin political markets - the informed special-interest groups - are acting in a way very much consistent with what one would expect of good capitalists. They are acting in ways to increase their own profits. In fact, I call these situations thin political "markets" - rather than political "processes" - because the key players approach their role much as they would in any 
other market: as self-interested profit maximizers. To these key players, shaping accounting rules to their benefit is just another way of building and sustaining a competitive advantage.

In this spirit, these players embody what modern economic theory considers the role of the firm in capitalism. They embody the spirit of Milton Friedman's famously influential call-to-arms - "the social responsibility of business is to increase its profits."15 Why, then, is there a problem with thin political markets?

The problem, of course, is that for profit-increasing behavior to be legitimate and desirable - for profit-increasing behavior to generate aggregate prosperity and wealth we must have a competitive process. No one individual, group, or organization can dominate the outcome. But thin political markets, by definition, are one-sided. In such situations, expert special-interests can shape the rules of the game unopposed.

Can this sort of behavior possibly be legitimate? Can this behavior possibly represent what Milton Friedman and others behind the development of modern economic theory had in mind?

\section{What is the "social responsibility" of managers in thin political markets?}

Political scientists have long known that that corporate managers use the political process in self-serving ways. ${ }^{16}$ As such, this is not a cause for great concern if the political process is well-attended - that is, if a diverse set of views across corporate participants and other interests groups representing labor, environment, consumer rights, etc., are represented in the political discourse. With such competition in politics, the selfserving lobbying of various special-interests groups usually does equilibrate. ${ }^{17}$

The problem with thin political markets is the absence of such political competition. The dominant special-interest group in a thin political market has an information edge over other stakeholders. Moreover, the issue being determined is so abstruse that it is outside the grasp of the general public. This leaves the dominant special interest uniquely positioned to shape the outcome in a thin political market. Under such circumstances, what is the "social responsibility" (to quote Milton Friedman) of that special-interest group? Is it still "to increase profits?” For example, is it legitimate for investment banks to pursue self-serving accounting rules when they have a unique and unrivaled ability to shape those rules?

The answers to these questions can be found in the same logic that motivated Milton Friedman and others to argue the merits of self-serving profit-maximizing firms. Recall that Friedman said it was the social responsibility of firms to increase profits - not their right, or their prerogative, or even their natural tendency, but their responsibility. Friedman was not making a descriptive statement about the world as it is, but a normative statement about the world as it should be. 
At first glance, a normative argument for self-serving behavior seems absurd. But the self-serving pursuit of profit is the engine of capitalism. In the presence of competition, profit-increasing behavior is what makes capitalism work. And when capitalism works, we get all of the remarkable things that a functioning capitalist society can deliver, such as the efficient allocation of resources across diverse human preferences and the capacity to empower individuals to seek their own economic destiny. Moreover, as numerous scholars of capitalism have pointed out, with the wealth that a capitalist society delivers, citizens in such a society are freed to pursue higher aims such as securing greater political freedoms (e.g., gay marriage) or immersing themselves in the arts and other leisurely pursuits. ${ }^{18}$

Thus, Friedman, when he argued for a social responsibility toward profit seeking, was making an ethical argument for capitalism - an ethical argument for all of the benefits that a functioning capitalist system can deliver. In ethical terms, profit-seeking behavior is a means to an end - the end being the various socially desirable properties of a well-functioning capitalist system.

Thin political markets, of course, have the same end. After all, the objective of the regulatory process underlying a thin political market is the enabling of the capitalist system. It is difficult to imagine a modern market-capitalist system effectively functioning without a system for appropriate accounting rules, or, for that matter, actuarial rules, auditing rules, and bank-governance rules.

But in a thin political market, we do not have the competition that makes selfserving, profit-seeking behavior okay. What we have, instead, is an informed and unopposed special-interest group that can, through profit seeking, capture the political process and opportunistically skew fundamental institutions of capitalism - such as accounting rules. And a market without well-designed basic rules of this nature can become wealth extracting rather than wealth creating. The unrestrained pursuit of profit in thin political markets can eventually upend both the functioning and the legitimacy of capitalism. The growing populist discord over income inequality and institutionalized corruption in the United States is perhaps an ominous warning sign that problems of this nature cannot be left unchecked.

With this understanding, it becomes apparent that the social responsibility of the informed special-interest groups in thin political markets cannot possibly be "to increase profits." Rather, their social responsibility is to preserve and advance the conditions under which the capitalist system can continue to thrive. Their social responsibility is to help design the rules of the game so that the game can be played freely, fairly, and effectively.

In thin political markets the corporate managers of the dominant, informed special-interest groups are no longer agents for their shareholders (in whose interests they would ordinarily seek profits) but rather are agents for the capitalist system as a whole. They are stewards of the system, with the objective of getting the rules of the game right. 
The notion that corporate managers have this dual agency - to shareholders in the context of competition and to the system as a whole in thin political markets - raises a number of issues. First, is such a dual agency legally permissible given current corporate law? Second, can such a dual agency be achieved in practice? How would managers know when to act in the interests of the system? How can they be held to account for it?

\section{Engineering change in thin political markets}

In the United States and in many other modern capitalist societies, officers and directors of a corporation have fiduciary duties to the corporation and its shareholders. These fiduciary duties are sometimes misinterpreted as requiring corporate managers only to pursue the direct interests of their shareholders via profit seeking. In reality, however, the law offers wide latitude to managers to do what is in the long-term interests of the corporation as a whole. As Supreme Court justice Samuel Alito noted recently, "While it is certainly true that a central objective of for-profit corporations is to make money, modern corporate law does not require for-profit corporations to pursue profit at the expense of everything else, and many do not do so.”19

Thus, there is nothing in the law to prevent corporate managers from acting in the interest of the system as a whole in thin political markets. Preserving the system of capitalism by preventing its capture in thin political markets is indisputably in the longterm interest of the corporation - because, after all, the corporate entity derives its legitimacy and its license to operate from the legitimacy of the capitalist system as a whole.

Even with the legal impediment to a dual agency being addressed, there is still a concern that managers cannot possibly be expected to serve two masters. Celebrated management scholars such as Michael Jensen have sometimes argued that managers need a single objective function to be effective at what they do. ${ }^{20}$ In reality, this line of argument is a red herring. Corporate managers routinely serve in multiple agency roles in practice. For example, if the executive officer of one corporation is on the board of another, she is a fiduciary to both corporations and holds dual agency. Numerous prominent (and highly effective) business executives such as Eric Schmidt and John Doer have served in such dual-agency roles.

But how do managers know when their agency to the system governs? How can they recognize thin political markets? In practice, such situations are actually easier to identify than they might first appear. For instance, when representatives of the largest investment banks and audit firms are invited to discuss with the FASB accounting rules for M\&A, and when no representatives from the general public are present at such meetings, it should be pretty clear to all parties present that they are now stewards for the system as whole.

Common sense and good leadership instincts can reliably alert managers to situations where they bear responsibilities to the system. Many other professions where such dual agencies exist seem to generally manage the competing responsibilities well. 
Consider, for example, public prosecutors, who bear dual responsibilities - to prosecute a given case to the fullest extent of the law in an adversarial system; and to advance the course of justice and equity as a whole. There are times when during the pursuit of a particular defendant at trial new information comes to light that exonerates the defendant. In such times, good prosecutors should - and, indeed, most prosecutors do - recognize that their responsibility to advance justice and equity trumps their responsibility to be adversarial with the defendant. A similar expectation of corporate managers in thin political markets is neither infeasible nor unreasonable.

The first step in achieving such a transformation is reexamining the curriculum in our nation's business schools and economics departments. Despite a general recognition among academics that profit-seeking alone cannot be the purpose of the corporation, the teaching of economics, finance, and corporate strategy remains largely uninfluenced by this view. A deep exploration of issues around the ethics of capitalism and profit-seeking is often relegated to courses taught outside business and economics departments. Such courses are usually optional to business and economics majors, so it is possible for these graduates to enter the workforce without a complete understanding of the ethics of profit seeking.

Deepening the curriculum in our colleges and universities is one way to engage the next generation of business leaders in conversations about their responsibilities to society in thin political markets. But these young leaders are incubated and promoted by the existing corporate elite and, moreover, the problem of thin political markets is current. So efforts to change behaviors in thin political markets must equivalently focus on senior business leaders.

Here, we cannot overstate the need for more focused and forceful mechanisms to emphasize managers' agency responsibility to the capitalist system in thin political markets. After all, the short-term economic incentives to act to the contrary are often too sweet to pass on. Here are three practicable mechanisms that can be introduced in thin political markets such as accounting rule-making.

First, managers lobbying in these political markets should be encouraged to publicly recognize their agency responsibility to the system. They should be encouraged to assert under penalty of liability that they are representing the public interest in their lobbying. This is akin to a professional oath a doctor is expected to take before being credentialed. In the context of accounting rule-making, I propose a scenario where, for example, when members of an investment bank are meeting privately with the FASB to discuss a rule change, all individuals present begin the meeting by affirming orally and in writing that the positions they are advancing are in the public's interest. This might seem like a superficial or an ineffective step, but research has shown that getting individuals to explicitly recognize their responsibilities can have a significant impact on their behavior. For example, results from experimental studies on issue framing have found that the simple act of declaring that a form will be completed truthfully reduces dishonesty when completing the form. ${ }^{21}$ 
Second, a group of subject-matter experts - e.g., academics, retired corporate executives, and retired regulators - should be invited to evaluate outcomes in various thin political markets. In accounting rule-making, I propose a decennial public review of the FASB's output by a group of experts who have no prior ties with either the FASB or its most active constituents such as the largest audit firms. Such a review will no doubt be imperfect, not least because the experts will be at a knowledge disadvantage relative to the insiders who shape outcomes in accounting rule-making. But the review will nevertheless shed some light on the political process and can serve as a follow-up accountability mechanism for managerial lobbying. If the results of such a review are publicized in civil society, managers and rule makers engaged in narrow capture will be at least subject to some reputational penalties.

Third, managers identified as exhibiting public leadership in thin political markets should be publicly felicitated. Social recognition plays an important role in stimulating competitive individuals to achieve their best. For example, many business leaders are motivated to build successful firms as much for the recognition they receive from doing so as for any monetary rewards. This is particularly the case beyond a certain threshold of wealth and income, where the marginal benefit of another dollar earned is often outweighed by the marginal benefits of social recognition. Leadership in thin political markets will seldom yield direct monetary rewards, so it is incumbent on us to find other ways to reward such leaders. By making senior managers aware of the nature of thin political markets and their changing responsibilities in these contexts, we can begin to celebrate those who show real leadership in these contexts. And on this front, business schools and the media have an important role to play. Just as industry titans are heralded in business school classrooms and on the covers of Fortune and Forbes for their commercial acumen, so too must they be celebrated for their public leadership in thin political markets.

\section{Conclusion}

Writing for The New York Times Magazine in 1970 about "the social responsibility of business," Milton Friedman said, "I have been impressed time and again by the schizophrenic character of many businessmen. They are capable of being extremely farsighted and clearheaded in matters that are internal to their businesses. They are incredibly shortsighted and muddle-headed in matters that are outside their businesses but affect the possible survival of business in general.",22

Reexamined in the context of the problem of thin political markets - and its potential to gradually but steadily erode the legitimacy of our capitalist system - this sentiment rings loud and true. After all, Friedman himself was very careful to acknowledge that his clarion call to profit-seeking in business had its limits. In his iconic and immensely influential book, Capitalism and Freedom, he argued that every business should pursue profits "so long as it stays within the rules of the game, which is to say, engages in open and free competition without deception or fraud.",23 
My own decade-long investigation into the determination of our corporate accounting "rules of the game" suggests that corporate managers have sometimes lost sight of this very important qualification. From time-to-time, certain corporate managers have seen it within their purview - their "social responsibility" even - to manipulate the very definition of profits in the spirit of increasing profits (e.g., by changing accounting rules). From the perspective of the average citizen invested in the market economy, there's no other way to see this behavior but as an example of the "deception or fraud" Friedman warned against. We have to get this to change.

\section{Endnotes}

${ }^{1}$ Financial Accounting Standards Board, “FASB Board Meeting” (minutes, FASB, May 31, 2000).

2 SDC Platinum, M\&A activity 1980-2012, accessed September 2013, http://thomsonreuters.com/sdcplatinum/.

${ }^{3}$ See, for example, Gregor Andrade, Mark Mitchell, and Erik Stafford, "New Evidence and Perspectives on Mergers,” Journal of Economic Perspectives 15, no. 2 (2001): 103-120.

${ }^{4}$ Financial Accounting Standards Board, “FASB Board Meeting” (minutes, FASB, September 29, 2000).

${ }^{5}$ Financial Accounting Standards Board, "Exposure Draft 201-R: Business Combinations and Intangible Assets-Accounting for Goodwill” (Norwalk, CT: FASB, 2001). Also see, Financial Accounting Standards Board, "Statement of Financial Accounting Standards No. 142: Goodwill and Other Intangible Assets June 2001.”

${ }^{6}$ Karthik Ramanna and Ross Watts, "Evidence on the use of unverifiable estimates in required goodwill impairment," Review of Accounting Studies 17, no. 4 (2012): 749-780.

${ }^{7}$ Cisco Systems, “Form 10-K for the fiscal year ended July 27, 2013,” accessed January 2014, http://www.sec.gov/Archives/edgar/data/858877/000085887713000049/csco-2013727x10k.htm.

${ }^{8}$ Public Company Accounting Oversight Board, "SAS No. 101: Auditing Fair-Value Measurement and Disclosures,” accessed January 2014, http://pcaobus.org/Standards/Auditing/Pages/AU328.aspx.

${ }^{9}$ Ernst \& Young to Financial Accounting Standards Board, Letter of Comment No. 131, file ref. 1033201R (Norwalk, CT: FASB, 2001).

${ }^{10}$ Brief of Defendant-Appellee Ernst \& Young LLP, Fait v. Regions Fin. Corp., 655 F.3d 105 (2d Cir. 2011) (No. 10-2311).

${ }^{11}$ For the original formulation of the collective action problem, see Anthony Downs, "An economic theory of political action in a democracy," The Journal of Political Economy 65, no. 2 (1957): 135-150; Mancur Olson, The Logic of Collective Action: Public Goods and the Theory of Groups (Cambridge: Harvard University Press, 1965).

${ }^{12}$ Elinor Ostrom, Governing the commons: The evolution of institutions for collective action (Cambridge, UK: Cambridge University Press, 1990). Also see, Gunnar Trumbull, Strength in Numbers: The Political Power of Weak Interests (Cambridge: Harvard University Press, 2012). 
${ }^{13}$ The notion of experiential knowledge has been explored in a rich management-science literature on organizational learning. See, for example, George P. Huber, "Organizational learning: The contributing processes and the literatures,” Organization Science 2, no. 1 (1991): 88-115.

${ }^{14}$ See, for example, Alexander Dyck, David Moss, and Luigi Zingales, "Media versus Special Interests," Journal of Law and Economics 56, no. 3 (2013): 521-553.

${ }^{15}$ Milton Friedman, "The Social Responsibility of Business is to Increase its Profits," The New York Times Magazine, September 13, 1970.

${ }^{16}$ See, for example, Thomas Stratmann, "Some Talk: Money in Politics. A (Partial) Review of the Literature,” Public Choice 124, nos. 1-2 (2005): 135-156; Amy J. Hillman, Gerald D. Keim, and Douglas Schuler, "Corporate Political Activity: A Review and Research Agenda," Journal of Management 30, no. 6 (2004): 837-857.

${ }^{17}$ See, for example, Stephen Ansolabehere, John M. De Figueiredo, and James M. Snyder, "Why is there so Little Money in Politics?” Journal of Economic Perspectives 17, no. 1 (2003): 105-130.

${ }^{18}$ See, for example, Amartya Sen, Development as Freedom (Oxford, UK: Oxford University Press, 1998); Benjamin M. Friedman, The Moral Consequences of Economic Growth (New York: Alfred A. Knopf, 2005).

${ }^{19}$ Burwell v. Hobby Lobby Stores, Inc., 2014 WL 2921709 - Supreme Court 2014. Also see, Lynn Stout, The Shareholder Value Myth: How Putting Shareholders First Hurts Investors (San Francisco, CA: Berrett-Koehler, 2012).

${ }^{20}$ Michael C. Jensen, "Value maximization, stakeholder theory, and the corporate objective function," Business Ethics Quarterly 12, no. 2 (2002): 235-256.

${ }^{21}$ See, for example, Lisa L. Shu, Nina Mazar, Francesca Gino, Dan Ariely, and Max H. Bazerman, "Signing at the beginning makes ethics salient and decreases dishonest self-reports in comparison to signing at the end,” Proceedings of the National Academy of Sciences 109, no. 38 (2012): 15197-15200.

${ }^{22}$ Milton Friedman, “The Social Responsibility of Business is to Increase its Profits,” The New York Times Magazine, September 13, 1970.

${ }^{23}$ Milton Friedman, Capitalism and Freedom (Chicago: Chicago University Press, 2002). 